\title{
Su lugar en la literatura
}

\author{
Por Margarita Sorock ${ }^{1}$ \\ Universidad de la Ciudad de New York (EE.UU)
}

Pinaud, Francisco (2012). Plátano en tentación y otras especies. Cartagena: Ediciones Tecnar.

Plátano en tentación y otras especies, así se titula la colección de diecisiete historias cortas -la gran mayoría inéditas- del conocido fotógrafo y gestor cultural Francisco Pinaud. A cada cuento lo acompaña una fotografía de fuertes contrastes en blanco y negro. Nos imaginamos que la fotografía, en algunos casos, inspiró el cuento que la acompaña; en otros, la expresión gráfica amplía

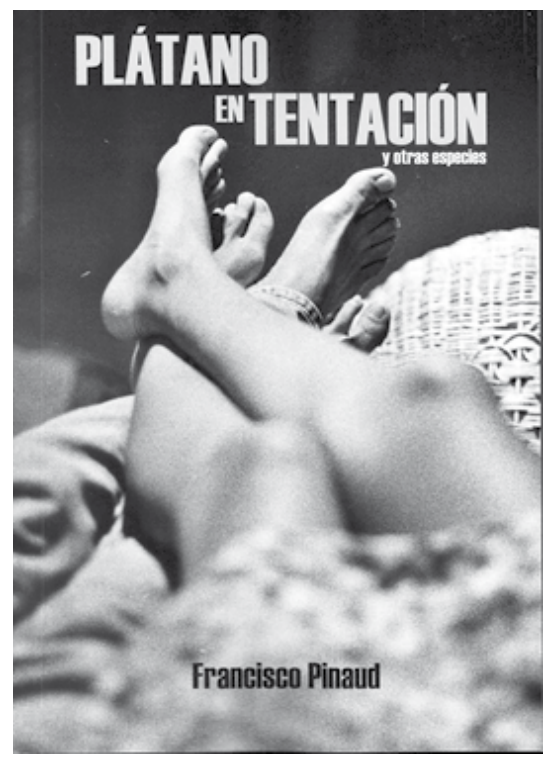
e ilustra el mundo del autor. No podemos sino dejarnos seducir por las imágenes visuales y entrar en un mundo cartagenero personal y único que Pinaud comparte con nosotros. El lector que lo conoce y lo estima no puede sino lamentar que se haya demorado tanto en abrirnos la puerta a su mundo y a su visión personal del amor cartagenero, con todo lo erótico, lo confuso y lo poético que eso implica.

Las diecisiete historias cuentan con un narrador anónimo. En sólo tres - "La caída de los cuerpos", "Borges y Él” y "Las criaturas de la playa"- el narrador cuenta sobre otras personas, a veces como si tuviera la habilidad de leer sus pensamientos y pronosticar sus destinos. Penetra el alma de Borges cuando éste llega a entender que Dios sí existe y obra a través de muchas personas con dones literarios: Cervantes, Shakespeare, y para gran sorpresa del poeta argentino, de Borges mismo. En "La caída de los cuerpos", el narrador transita por los pensamientos, sentimientos y actos secretos de Josefina, la

\footnotetext{
${ }^{1}$ Doctora en Literatura y Lenguaje en Español de la Universidad de la Ciudad de Nueva York (CUNY). Ha sido profesora de literatura en la Universidad Jorge Tadeo Lozano, Seccional del Caribe, y en la Universidad Tecnológica de Bolívar. e-mail: marelso@hotmail.com
} 
joven que sube en un ascensor al octavo piso del Edificio Ganem, "[...] la única construcción sobresaliente entre el apretado conjunto de casas viejas del centro de la ciudad" (17). Josefina tiene una cita clandestina con su novio, quien vive en el octavo piso.

En el ascensor tropieza con una joven que, según Josefina, emana, "[...] gracias a la certera precisión de su belleza, una inasible noticia de felicidad, de apetencias satisfechas" (18). La joven es de su misma edad, más no de su clase social. Josefina es pobre, pero se arregla bien y sabe disimular su situación. Al final, la sorpresa será para el lector. Ese alto edificio le sirve a la bella joven como instrumento de suicidio. El narrador no especifica quién se arroja, pero guía al lector a la conclusión más probable, ya que se ha preocupado por destacar la altura del edificio, y a través de Josefina, por describir a la elegante joven que subió al piso de arriba.

En "Las criaturas de la playa", el narrador nos cuenta la breve historia de la atracción que siente Máximo Gómez por Marla, al verla en las playas de Caño del Oro. Máximo, casado con una exitosa odontóloga, aprovecha unos días libres para irse solo -y soltero- a la playa. La primera vez que ve a Marla, ella está jugando con su perro. La segunda vez, la ve sola, y la conquista con dos alegrías con coco y anís que le entrega con el vendedor. Marla se levanta y camina hacia el manglar. Máximo la sigue (es más lo que no nos ha dicho el narrador, que lo que nos ha contado). El cuento es como unas breves pinceladas sobre el papel, que conllevan a la exitosa conquista de Marla por Máximo. Sabemos que en la vida real, el encuentro se abre a muchas posibilidades: Marla puede estar yendo a una cita con otro; Marla puede rechazar a Máximo. Pero el narrador construye el cuento de tal manera que no hay sino una posible conclusión: el exitoso -léase amoroso- encuentro entre dos atractivos adultos, solos en las playas de Caño del Oro (lo suficientemente alejada de la vida cotidiana cartagenera para servir como su paraíso de amor).

En las catorce historias restantes, el narrador, también anónimo, relata sus propias experiencias en primera persona. La técnica da un toque íntimo que personaliza los pensamientos, sentimientos y acciones. Por la temática, el lector se atreve a pensar que es un mismo narrador, un alter-ego del autor que nos cuenta sobre sus experiencias con el amor, el sexo, la amistad y la ciudad. Martina, Luisa, Elisa, Luciana, Marla, Josefina, Anita, Sonia, Olimpia y Vilma, desfilan por las páginas del libro y por el cuerpo y conciencia del narrador. También hay algunas, como la doctora de caderas cimbreantes de "Vuelve y tira que no me has dado", cuyos nombres no sabemos, pero que dejan su huella en el narrador. 
En la historia titulada "Plátano en tentación", el narrador se detiene en una idea que su amigo Pascual atribuía al escritor inglés Lawrence Durrell: "una mujer sirve para tres cosas: para amarla, para odiarla o para hacer literatura" (53). Y analizando la época de su amistad con Pascual desde la perspectiva actual, se da cuenta de que predominaban en su memoria las mujeres que "[...] se convirtieron en literatura [...] después de haberlas amado" (53). En "Blanco y negra”, la historia más desarrollada de la colección, el narrador se cuestiona su compromiso con el oficio de escribir: “¿Vivía yo las cosas para después contarlas o las contaba solo porque las había vivido"? (91). Formula una respuesta tentativa: "Tengo la sospecha de que los sucesos me llegaban con la única finalidad de que se los narrara a otros. En ese sentido, los personajes sí vienen en busca de un autor" (91). La historia es sobre un triángulo amoroso entre el narrador, la negra Vilma -su empleada de servicio doméstico- y Luisa, la rubia que entraba y salía de su apartamento y su corazón.

Cada una de las mujeres sabe de la existencia de la otra, pero nunca se cruzan. Vilma llega en el momento en que parece que Luisa sale para siempre, pero su ida no fue permanente. La desigualdad social y la relación de poder entre patrón y empleada le pican la conciencia al narrador, a la vez que disfruta el sexo con Vilma. Luego concluye, buscando una explicación "literaria" para los pequeños episodios de remordimiento de conciencia: "Vilma no llegó porque quería trabajar. Llegó a un sitio, su sitio, que la estaba esperando en las diez páginas de esta historia" (91).

Aún cuando el narrador no esté contando sobre sus experiencias amorosas, el amor carnal está presente. En “Geografía nacional”, el narrador nos cuenta, ya de segunda mano, sobre las experiencias de su amigo Eduardo, cuando éste buscaba un aislado sitio a la intemperie para hacer el amor con su novia. Justo cuando ellos creen que lo encuentran, advierten que hay otra pareja haciendo el amor. En "El regreso", el narrador es el nuevo inquilino de un viejo apartamento donde descubre libros y papeles dejados por el anterior ocupante: "Evidentemente aquí había ocurrido un episodio de amor, de los miles que suceden a diario en el mundo" (77). "En la puerta del hotel", el narrador es testigo de lo que va a ser amor carnal entre dos mujeres. Las describe y les da nombres: la más alta, Anita, y la baja, Sonia. El discreto y secreto comportamiento de la pareja no pasa desapercibido y queda en la memoria del narrador, quien se imagina la escena de amor entre las dos. El sitio está grabado en la conciencia del narrador y la calle queda alterada permanentemente por su recuerdo. En la gran mayoría de los casos, el narrador es un alegre cómplice en el amor carnal; pero a veces lo confunde con el 
espiritual. Esto lo motiva a hacerse amigo de las cuatro hermanas Flórez, generosas con sus cuerpos que prestaban a cambio de dinero y trago. Cuando logra llevar a Olimpia, la menor, a la Tenaza, cree, ingenuamente que lo compartido irá más allá de lo erótico (67).

En varias ocasiones el narrador ve el amor carnal como una competencia entre él y su pareja. En "Extensión de dominio", reflexiona: "Siempre ganaba ella. Siempre era yo el perdedor de su cuerpo, porque a duras penas me quedaba la miríada de cabellos dorados sobre la cama, la huella dactilar del paso de su cuerpo por el mío que con calculada y repentina impiedad me asaltaban después" (32). Los juegos que el narrador inventa con Luciana son mejores que los de la selección colombiana de fútbol. "No hay primer tiempo ni descanso ni segundo tiempo con ella. Ella y yo jugamos todos los tiempos" (115).

En sólo una ocasión el amor erótico despierta un sentido de culpabilidad en el narrador, no por el acto sexual en sí, sino por la desigualdad social entre él y su pareja, Vilma. En "Blanco y negra" nos cuenta: "Pagaba por ella una mínima parte de un todavía más mínimo salario para que pusiera sus manos sobre mis cosas revueltas. Y recibía a cambio mucho más, porque nadie habló de complacer al patrón" (81). Casi escuchamos el debate dentro del narrador: ¿Debería pagarle más? ¿El pago borrará su triste pasado? El narrador llega a saber un poco sobre la vida de Vilma y entiende que sólo uno de los "episodios de despojo, pobreza y abandono" que había sufrido ella habría bastado para volverlo loco (89). Su agradecimiento se expresa literariamente: inmortalizarla en el cuento.

La literatura es el gran regalo que recibimos del prójimo con los dones que éste recibe del Creador. Y una figura literaria que Pinaud admira bastante es la del poeta cartagenero Luis Carlos López. El poeta aparece en varias historias como una figura admirada. En el muy breve cuento titulado "El poeta", el narrador lo ve en un ambiente cotidiano, en una reunión que incluye a las estrellas de las letras en la Cartagena de los años 1940 y 1950. El narrador tiene la fantasía de acercarse al poeta, extenderle la mano y decirle "iQué hay, tuerto!", pero no se atreve. Aunque no lo expresa explícitamente, Pinaud hace referencia a la poetización de lo cotidiano en Luis Carlos López, la irreverencia con que selecciona sus temas, la sátira de la sociedad, su humor mordaz y su habilidad de poner el dedo en la llaga, exponiendo las debilidades y flaquezas de Cartagena.

Para Pinaud, Cartagena forma parte integral de sus historias, reforzadas con las imágenes que las acompañan. Siendo fiel a la tradición del Tuerto López, no es una Cartagena ni histórica ni 
heroica, sino una Cartagena que inspira afecto y nostalgia, a pesar de su deterioro e improvisación. Es una Cartagena más inocente y menos desarrollada que la de hoy: la ciudad de los años ochenta, inmediatamente anterior al cambio (por haber sido reconocida como Patrimonio Mundial de la Humanidad). Los espacios del centro histórico han perdido su significado original, pero aún no se han asumido como importantes reliquias del pasado. Así es que la agencia inmobiliaria de Josefina, protagonista de "La caída de los cuerpos", "quedaba en una casona de tres pisos que distribuían en cantina y billar, en la primera planta, una 'academia' y un salón de belleza en la segunda y la agencia, en la tercera (17).

En "Plátano en tentación”, el Edificio Cuesta, sobre la Plaza Santo Domingo, en pleno deterioro, fue la sede de pequeños dramas de gente venida a menos, como don Teo, que conservaba los recortes de revistas de todas las reinas de belleza pegados "en las paredes salitrosas de ese albergue de lástima en donde se iba muriendo poco a poco" (55). Por fin los vecinos descubren a don Teo muerto en su apartamento. El narrador se acerca al edificio y rescata una foto que había tomado del ya fallecido protagonista de la historia. Por último, la culinaria cartagenera no se escapa, ya que el título del libro, y de una de sus historias más largas, es un tributo a una receta tradicional cartagenera, el "plátano en tentación", preparada con Kola Román. Está también el mote de queso en la historia titulada "Un estado de gracia", "que reverberó y rebosó la olla" (45), mientras Marla y el narrador se entregan a "la sevicia de placer" y a la "alevosía del gozo" (45). Por su parte, Máximo, en "Las criaturas de la playa", conquista a otra Marla (o tal vez la misma) con dos alegrías con coco y anís, dulces caseros tradicionales de la ciudad.

Plátano en tentación y otras especies es, así mismo, un documento de valor histórico. Nos sitúa en la Cartagena de los 80 , en una ciudad venida a menos, luchando por conservar, y a veces improvisar, su dignidad. Es el fin de una época cargada con nostalgia e incertidumbre hacia el futuro. Los personajes de la narrativa descubren un mundo, tal vez diferente del que esperaban, pero uno en que es todavía posible celebrar el amor. Viejas confusiones ceden ante lecciones del nuevo entendimiento de la realidad. La libertad en el ámbito personal se asume sin convertirse en libertinaje y la exquisita razón de existir: inmortalizarse en las páginas de estas narrativas. Plátano en tentación y otras especies contiene relatos tan personales como universales: un equilibrio perfecto. 
